\title{
How to fix a broken heart?
}

\section{Clues about how human hearts form hint at routes to cell-based therapies.}

Heart disease kills more people than any other condition, yet cell therapies for it remain frustratingly elusive. On page 113 of this issue, Kenneth Chien of the Massachusetts General Hospital, in Boston, and his colleagues report a finding that could move this treatment closer to reality: human 'progenitor' cells that generate various types of heart tissue as they develop.

Chien's work remains a long way from the clinic, however, and clinical trials of other cell types for heart ailments have yielded mixed results. "Even the most ardent advocates are calling the long-term benefit modest," says Christine Mummery, a stem-cell researcher at Leiden University in the Netherlands. That leaves open the question of what cell types, if any, could turn stem-cell research into reality for patients with heart disease.

Chien's team had previously identified, in mice, heart progenitor cells that expressed a transcription factor called Isl1 (A. Moretti et al. Cell 127, 1151-1165; 2006). Their latest paper finds that these cells also exist in humans. After identifying cell populations in human fetal tissue, the researchers produced them from human embryonic stem cells. They also showed that the cells were multipotent - they could generate more progenitors as well as the major heart cell types of heart-muscle, smoothmuscle and blood-vessel cells.

The work provides an explanation for how heart cells differentiate. Although the cells exist for just a couple of days in mice, they persist for weeks in human fetuses. This implies that cells do not immediately differentiate into the major types of heart tissue, but that the heart is built from a pool of multipotent cells that persists and differentiates as the heart grows. The findings suggest that an effective approach to cell therapy might be "to put heart progenitors in, because that's the way the heart is built in the first place", says Chien.

Philippe Menasche, a cardiac surgeon at the Georges Pompidou European Hospital in Paris, has some doubts. He calls the work "a very interesting basic research paper", but says that "when you are identifying progenitors like this, the first question is, 'is it possible to isolate these cells selectively and use them [to treat patients]'?" And that isn't possible, he says, because the telltale Isl1 is a protein that turns genes on and off and so must lie deep within the nucleus of the cell. Most robust technologies to purify cells do so through proteins that are found on the cell surface.

\section{Early stages}

At the moment, Chien has to use genetically engineered fluorescent tags to identify cells that produce Isl1. Wariness over using genetically engineered cells, plus the fact that his cells are not genetically matched to patients', make

\section{SELECTED HEART CELL-THERAPY TRIALS}

Trials of bone-marrow cells dominate the field of heart stem-cell therapy. All except the Osiris trial use patients' own cells.

\begin{tabular}{|c|c|c|c|}
\hline Sponsor & Cell type & Phase & Expected enrolment \\
\hline Bioheart, Munich, Germany & Skeletal myoblasts & II/III & 390 \\
\hline Osiris Therapeutics, Columbia, Maryland & Mesenchymal stem cells & II & 220 \\
\hline $\begin{array}{l}\text { Cedars-Sinai Medical Center, Los } \\
\text { Angeles, California }\end{array}$ & Cells from heart biopsies & I & 30 \\
\hline Ministry of Health, Brazil & Bone-marrow cells & III & 300 \\
\hline $\begin{array}{l}\text { Johann Wolfgang Goethe University } \\
\text { Hospitals, Frankfurt, Germany }\end{array}$ & Bone-marrow cells & III & 200 \\
\hline Barts and The London NHS Trust, UK & Bone-marrow cells & II/III & 165 \\
\hline Seoul National University Hospital, Korea & Circulating blood cells & II/III & 116 \\
\hline Source: clinicaltrials.gov & & & \\
\hline
\end{tabular}


cardiomyocytes, but that doesn't mean they aren't helpful, argues Menasche. "It doesn't imply they don't have any effect," he says.

Several large-scale trials are under way to determine whether bone-marrow cells might instead benefit patients through the 'paracrine' effect: secreting growth factors that encourage hearts to grow new blood vessels and thereby preserve existing heart tissue. So far, says Mummery, the results have been ambiguous: the cells seem to be safe, but are not particularly effective.

But others think that the efficacy of the cells has not yet been tested properly. Cells delivered too soon after a heart attack are unlikely to survive, for example, and their effects in very sick patients might be masked if healthier patients are also included in a trial, says Makkar.

Approaches using skeletal-muscle cells have also been mixed. In 2002, Menasche led a large clinical trial studying whether injecting skeletal muscle into the heart could restore heart function. In 2006 that trial was stopped early because of a lack of efficacy, and Menasche has since decided to work on cells derived from embryonic stem cells. These readily generate beating cardiomyocytes in laboratory dishes, but are difficult to integrate productively into damaged heart tissues. Problems include purifying cells, getting enough of them, making sure they are not attacked by the immune system and controlling for the possibility of unwanted growth - to say nothing of making sure that the introduced cells beat in time with the motion of the failing heart.

Most bone-marrow trials focus on blood-forming stem cells, but another cell type found in bone marrow, called mesenchymal stem cells, is also being studied. Joshua Hare, of the University of Miami in Florida, says his team will soon report results from a phase II trial of mesenchymal stem cells, run by Osiris Therapeutics of Columbia, Maryland, showing that the cells both engraft as new cardiomyocytes and help through the paracrine effect.

Indeed, Hare believes that doctors might eventually use a variety of cell therapies to treat heart disease. Mesenchymal stem cells could be used as a first-generation therapy, followed perhaps by cells derived from cardiac biopsies, followed by other cell types that have not yet entered clinical trials. He predicts that cardiac cell therapy will follow the same path as antibiotics. "Just because we have third-generation cephalosporins now," he says, "doesn't mean that penicillin didn't work."

Monya Baker

\section{W \\ SPOOKY COMPUTERS CLOSER TO REALITY \\ Solid-state quantum processing demonstrated. www.nature.com/news \\ Italians sue over stem cells}

Three scientists are appealing against the Italian government's decision to exclude human embryonic stem cells from a recent call for proposals to fund stem-cell biology.

The scientists' lawyer, Vittorio Angiolini, who specializes in bioethics and human rights, filed the appeal with Rome's administrative court on 24 June. He argues that excluding human embryonic stem cells infringes on the constitutional freedom of scientific research. The use of established lines of human embryonic stem cells in research is legal in Italy.

The original draft of the funding call did not exclude any type of stem cell. "We don't know where the sentence that was added came from," says Elisabetta Cerbai, a pharmacologist at the University of Florence who is one of the appellants. "But we suspect that a compromise deal may have been made at high political levels."

The stem-cell research fund, run by the ministry responsible for health, has a turbulent history. In 2007, the then health minister, Livia Turco, cancelled a $€ 3$-million (US\$4.2-million) fund after some scientists complained that monies were being distributed without a public call for proposals and without appropriate peer review. At the time, Turco referred to the people complaining as "gangsters", but agreed to start again, with an $€ 8$-million pot and transparent reviewing procedures.

The centre-left government to which Turco belonged fell in spring last year. The following June, Turco's successor,

Ferruccio Fazio, established a committee of experts to draft a call that he promised would be administered in a transparent way.

Giulio Cossu, a developmental biologist at the San Raffaele scientific institute in Milan and one of the five members of that committee, says that the group formulated a carefully worded text that would neither exclude any type of stem-cell proposal, nor incite controversy.

But when that text became public, a sentence had been added that explicitly excluded projects with human embryonic stem cells. It appeared online after a 26 February meeting of the State-Regions Conference, the body comprising representatives of the 20 Italian regions

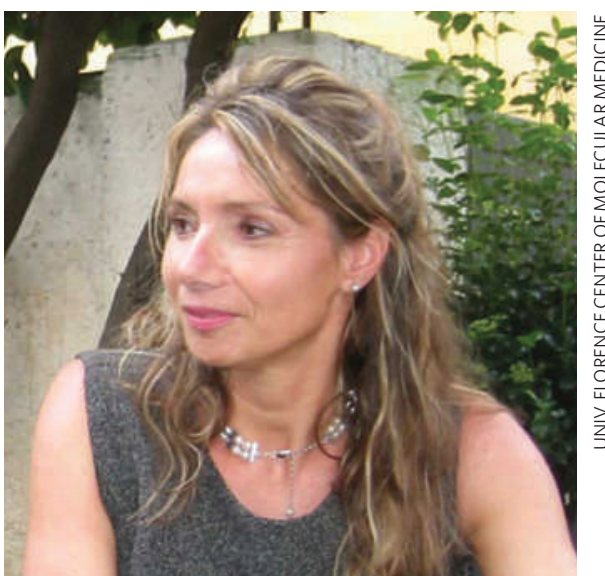

Stem-cell proponent Elisabetta Cerbai.

that decides how national health funds are distributed. "I was obviously disappointed," says Cossu, who notes that he joined the committee on the condition that there would be no exclusions based on ideology.

In media interviews at the time, Fazio dismissed rumours that the sentence had been added by someone within his ministry. He declined to comment to Nature, but in media reports has said that the sentence was added by the regions. However, the representative for Tuscany, Enrico Rossi, said publicly that no changes were made or requested when it was discussed by the conference.

Angiolini argues that "the ministry can change the text of the call only with the regions' consent".

"Our appeal is a matter of principle," says Cerbai. "Politicians should decide strategic research objectives and leave scientists to choose how best to achieve those objectives."

The other two appellants are Elena Cattaneo, a neuroscientist at the University of Milan, and Silvia Garagna, a developmental biologist at the University of Pavia. The three are financing the action with their own money.

The case is likely to be heard by the court in the first half of July, before the funding call's closing date of 20 July.

"We expect to win," says Cerbai. But if that does not happen, they hope to take their appeal to a higher court. Alison Abbott 